\title{
Features of legal regulation of state financial control of sustainable development projects
}

\author{
Sergey Shokhin*, Elvira Shokhina \\ Moscow State Institute of International Relations (University) of the Ministry of Foreign Affairs of the \\ Russian Federation, Moscow, Russia
}

\begin{abstract}
Sustainable development is the key point for scientific discussion in the contemporary world especially after the UN General Assembly introduced the sustainable development goals (SDGs). This paper is focused on the control and accountability issues related to financing of sustainable development goals implementation. The fundamental changes in public policy inherently cause more expectations in the society about accountability and efficient control and audit in public finance. The comparative method with reference to international experience is predominantly applied in the research. The paper emphasizes that strategic audit with its forms and methods is the most relevant for sustainable development projects' audit. Strategic audit should rely on the modern information technologies including the big data analysis. The increasing role of the Accounts Chamber of Russian Federation in the national goals and the SDGs achievement monitoring is highlighted in the article. The paper contributes both to the theoretical approaches to forms and methods of public audit and to the practitioners' discussion around the best practices in public finance audit.
\end{abstract}

\section{Introduction}

The Russian Federation has joined the efforts to achieve the Sustainable Development Goals (SDGs) set up at the United Nations General Assembly by resolution A/70/L.1. on September 25, 2015. To achieve these goals, the countries including Russia have undertaken to independently develop their own sustainable development strategies, plans and programs. The implementation of these strategies, plans and programs requires the corresponding financing strategies. At the same time, it is expected to organize adequate control over the SDG achievement means in order to ensure the effective use of financial resources to facilitate the implementation of the new sustainable development agenda. ${ }^{1}$

\footnotetext{
* Corresponding author: doctorsos07@,rambler.ru

${ }^{1}$ Sustainable Development Goals (SDGs) were set up in 2015 by the UN General Assembly as "the blueprint to achieve a better and more sustainable future for all". The resolution of the General Assembly named these goals the 2030 Agenda. The final document of the General Assembly Transforming Our World: The 2030 Agenda for Sustainable Development lists 17 global goals and 169 targets. Official website of the UN General Assembly: http://www.un.org/ru/ga/
} 
The directions of the public financial control in view of the new SDG-related tasks were stated at the international level in the Moscow Declaration adopted at the $23^{\text {rd }}$ Congress of the International Organization of Supreme Audit Institutions (INTOSAI) in Moscow in September 2019.

The Declaration emphasizes the importance of independent external oversight of the achievement of goals approved at the national level including the Sustainable Development Goals. The global fundamental changes in public audit ${ }^{2}$ and public policy have given rise to a new context and new expectations about the operations of financial control authorities. These changes include, among other things and in the first place, the adoption of the 2030 Agenda for Sustainable Development and the SDGs by all the United Nations member states, which implies an appropriate assessment and control level ${ }^{3}$. At the same time, the solution to the set tasks is guaranteed by the changes caused by a revolution in the collection, accumulation and processing of data based on the use of the increased opportunities of digital technologies.

With that in mind, state financial control authorities are designed to support more effective, transparent and informative accountability for results taking into account the complexity and comprehensiveness of government actions required to achieve national priorities and the SDGs. The achievement of new global and national goals requires a resultbased approach to governance to ensure government accountability to the parliament and the public. There is a need to promote the development of accountability based on professional responsibility, trust and a balanced approach to performance measurement. Accountability for results is more difficult to implement in practice, and government authorities are still learning the skills of result-based budgeting and the establishment of non-financial performance indicators.

Financial control authorities, on their part, intend to develop a strategic approach to public audit in order to support the achievement of national priorities and the SDGs. They should pay special attention to the government program and policy development stage, where the link between programs and policies and outcome ratios is formed. If such a need arises, one should focus on assessing the final effects when auditing the implementation of individual programs or the activities of separate government authorities. In line with the principle of the whole-of-government approach to audit, public financial control authorities should pay thorough attention to actions at different government levels and their consistency with the key indicators (municipal, regional and national SDG-related indicators).

At the current stage, public financial control authorities should develop a strategic approach to public audit in order to support the achievement of national priorities and the SDGs. To do that, it is necessary to develop and implement the methodologies for conducting a set of audits aimed at assessing the government ability to achieve the set goals; assessing the maturity of the strategic governance system (goal setting, aligning of strategies with national goals, feedback and due result-based control). One should assess the effectiveness of the interaction between various government levels, the synergy between various government programs, policies and strategies. Objectively, control authorities have good opportunities to assess the consistency of the public policy and to focus on cross-cutting issues and problems permeating the entire public administration sector as the control measures cover the entire spectrum of financial activities of the state. At the same time, public financial control authorities can contribute to a more effective use of experimental knowledge by the society and widespread introduction of experimental approaches in the

\footnotetext{
${ }^{2}$ Supreme Audit Institutions and Good Governance: Oversight, Insight and Foresight. OECD Public Governance Review. Paris: OECD Publishing. 2016.

${ }^{3}$ Measuring sustainable development. Report of the Joint UNECE/OECD/Eurostat Working Group on Statistics for Sustainable Development. New York and Geneva: UN 2008.
} 
implementation of government programs, strategies and policies within the framework of the development of proposals for improving the financial system in general and its individual sectors. They can use their diverse experience and expertise to promote high-quality public administration and inclusivity in socially important spheres related to the SDGs (environment, education, healthcare, gender equality, and others).

There are being developed relatively new public audit forms and methods adequate to modern tasks. Thus, public financial control authorities can audit the effectiveness of monitoring of the achievement of national goals and the SDGs to assess the preparedness of national statistical systems. It is also possible to assess inclusivity within the framework of an analysis of mechanisms for the achievement of national goals, the establishment of program and project indicators, the implementation of projects and programs aimed at specific sustainable development goals and goals approved at the national level.

At the same time, it should be noted that there is a need in the qualitative improvement of the effective interaction with stakeholders to identify and analyze issues of national interest, which will facilitate the adoption of reasoned decisions regarding government programs, projects or individual measures.

Despite the importance of the issues under consideration, this subject is almost not studied in the Russian legal science.

One may come across a few publications, where the issues of government program financing and strategic audit are mentioned casually, as secondary ones, not being the main subject thereof.

Problems of the information support of strategic audit and the use of modern information technology for financial control purposes are not reflected in the legal science at present, although certain steps in this direction are outlined.

It is assumed that this article will set in motion filling of the said gaps in the Russian financial law doctrine.

\section{Legislative Framework for the Control over the Financial Support of Sustainable Development Goal Implementation Programs in the Russian Federation}

In the Russian Federation, the legislative framework for strategic audit is at the initial development stage. The Federal Law on the Accounts Chamber of the Russian Federation introduced provisions granting the Accounts Chamber the possibility to conduct strategic audit. ${ }^{4}$

The Accounts Chamber is responsible for the audit of feasibility and effectiveness of achieving the strategic goals of the socio-economic development of the Russian Federation; determination of the efficiency and compliance of the procedure for forming, management and disposal of federal and other resources with the regulatory acts of the Russian Federation including for the purposes of strategic planning of the socio-economic development of the Russian Federation; development of opportunities and methods of audit (control) of the efficiency of forming, management and disposal of federal and other resources including the selection and assessment of the key national ratios and indicators of the socio-economic development of the Russian Federation.

Consequently, the functions of the Accounts Chamber include preparation of proposals for the establishment of a system of the key national ratios (indicators) that determine the level and quality of the socio-economic development of the Russian Federation as well as

${ }^{4}$ See: Art. 5, 13, 14, 16, 24 of Federal Law No. 41-FZ of April 5, 2013 On the Accounts Chamber of the Russian Federation // Collection of Legislative Acts of the Russian Federation No. 14 of April 8, 2013, Art. 1649. 
the choice of assessment criteria and methods; assessment of the impact of internal and external conditions on the actual level of achievement of goals of the socio-economic development of the Russian Federation; assessment of the efficiency of forming, management and disposal of federal resources to ensure the socio-economic development of the Russian Federation.

To perform these functions and tasks, the Accounts Chamber has quite ample powers that allow to perform qualitative analysis and bring forward proposals on the structure of macroeconomic and other key ratios (indicators) of the socio-economic development of the Russian Federation as well as the criteria and methods for assessment thereof.

The law stipulates that the Accounts Chamber carries out control, expert and analytical activities, inter alia, in the form of strategic audit. Strategic audit is applied to assess the feasibility, risks and consequences of the implementation of strategic goals of the socioeconomic development of the Russian Federation. Final (target) and achieved (current) values of the key national ratios reflecting the degree and quality of the implementation of socio-economic effects and cumulative effects of the socio-economic development of the Russian Federation are subject to assessment.

An actively applied part of strategic audit is the audit of government programs of the Russian Federation (federal target programs) in terms of compliance of the course of their implementation and results with the set requirements, justifiability and meeting the schedules of the implementation of individual work stages and information about their resource support as well as the correlation between the results and spent federal resources. Federal innovative projects of a high-risk nature are assessed based on an analysis of the efficiency of the implementation of a set of projects with similar goals and characteristics.

The correlation of methods of carrying out the activities of the Accounts Chamber is changing according to the specifics of strategic audit tasks aimed at the achievement of sustainable development goals. Monitoring and analysis gain the utmost importance. Monitoring is used to collect and analyze information about the subject and activities of the audited object on a systemic and regular basis. The expert assessment method is actively used. The Accounts Chamber examines and gives opinions on government programs of the Russian Federation including federal target programs.

From the methodological standpoint, strategic audit is carried out based on performance audit and compliance audit using specific methods required to control financial activities aimed at the achievement and implementation of the SDGs. The greatest attention is paid to preliminary control carried out in the form of an examination. Monitoring is used for current control purposes. The obtained data are summarized in the course of an analysis.

Taking into account the provisions of the INTOSAI Moscow Declaration, the Accounts Chamber of the Russian Federation has developed a strategic audit standard. ${ }^{5}$ Among the strategic goals, the Standard singles out the goals of sustainable development of the Russian Federation in various areas. The Standard clarifies the concept of a "program- and goaloriented instrument" as a document that defines strategic goals and is developed for their implementation, contains activities, financial and other resources.

The Standard determines that strategic audit can be conducted in the form of preliminary audit, operating control and follow-up audit by organizing and carrying out of control, expert and analytical activities including the ones involving continuous monitoring of program implementation.

Preliminary audit covers an assessment of the feasibility of strategic goals, the achievement of which is stipulated by the corresponding programs at their development or implementation stages. Results of examinations previously conducted by the Accounts

\footnotetext{
${ }^{5}$ See: Accounts Chamber of the Russian Federation. External State Audit (Control) Standard. State audit standard 105 Strategic Audit // http://www.audit.gov.ru
} 
Chamber, an assessment of planned or ongoing measures of direct state influence can be taken into account.

Operating control stipulates continuous monitoring of program implementation, when the current achievement of strategic goals is controlled and assessed. Continuous monitoring of program implementation can also include monitoring of risks and factors of their implementation in order to make a real-time forecast of the impact of internal and external conditions including risks on the achievement of strategic goals of the programs.

Follow-up audit means control and assessment of the effectiveness of the achievement of strategic goals through the verification and analysis of the actual level of achievement of the target ratios and indicators of the corresponding programs, the assessment of the final effects from the implementation of strategic goals including taking into account the actual immediate and final results of direct government influence, other external and internal factors and conditions.

Such methods of control, expert and analytical activities as verification, analysis, examination and monitoring can be used within the framework of strategic audit.

Strategic audit is aimed at assessing the feasibility, risks and results of the achievement of strategic goals including the assessment of the corresponding programs. The feasibility of strategic goals is assessed to determine the probability and possibility of the achievement of strategic goals by assessment of the corresponding programs both at their development stage and in the course of their implementation. The assessment of the feasibility of strategic goals may also include an assessment of the organizational maturity or functionality of the system of management of the corresponding program.

The assessment of risks of the achievement of strategic goals includes an analysis and assessment of factors that can have a negative impact on the achievement of strategic goals including by means of assessment of strategic planning documents developed within the framework of forecasting and goal setting. Risks are assessed in order to determine the presence and the degree of impact of internal and external factors on the achievement of strategic goals including, inter alia, an assessment of risks of the corresponding programs or direct government influence aimed at their achievement.

Results of the achievement of strategic goals are assessed in order to establish and evaluate the immediate and final results as well as the final effects planned or obtained in the course of program implementation and direct government influence aimed at the achievement of strategic goals.

The goals or issues of strategic audit can also be aimed at the assessment of such parameters as target and forecast values of the socio-economic development stipulated by the programs including strategic planning documents developed within the framework of goal setting, forecasting, planning and program development, risks and importance of activities of the parties to strategic management, relevance of programs for the achievement of strategic goals, justification of strategic goals and results, consistency of the system of incentives that is under development or is already developed, mutual coherence and complementarity of strategic goals, direct government impacts and results, immediate causal effect of direct government impacts on the achievement of strategic goals, wide distribution of program results and direct government impact in terms of territorial or branch coverage, coverage of various target groups, stability of actual or expected results and effects in the long run.

By the implementation of the reviewed goals and objectives, functions and powers, the Accounts Chamber of the Russian Federation embodies its proclaimed mission to promote fair and responsible public administration as a prerequisite for the sustainable development of the Russian society, helps government authorities, state and public organizations to create a long-term picture of the socio-economic state of the country and understand the complex 
of risks in the achievement of sustainable development goals. ${ }^{6}$

The key feature of government programs is mandatory co-financing from the federal budget and the budgets of the constituent entities of the Federation. In the majority of cases, the constituent entities of the Russian Federation where government programs are implemented should draw up their own similar regional programs being an integral part of the national ones, and provide for their financing. In this respect, financial resources allocated by the regions should be controlled by control and accounting authorities of the constituent entity of the Federation. To do this, the law stipulates the possibility of conducting joint and parallel audits of the federal and regional accounts chambers. However, the competence of regional control and accounting authorities in relation to the control over the justification and implementation of sustainable development programs is not consolidated in the law. ${ }^{7}$

\section{Conclusions}

The transition to the program- and goal-oriented method of allocation of funds to finance the activities aimed at the achievement of sustainable development goals involves the use of adequate specific forms and methods of government control over such expenses.

All links of the state control system are involved in the process of control over program expenses, both external control authorities and financial control authorities within the executive branch of government and at all levels of the budget system.

An adequate control type in the form of strategic audit has been developed and enshrined in the law to control program expenses; strategic audit is among other things based on proven performance audit and compliance audit methods applied to indicative planning documents at different stages of their development and implementation.

Preliminary control that is the analysis of the justification and risks of the program implementation gains particular importance. The preventive function is the major one in this case.

In current control, such control method as monitoring prevails. A periodic analysis of the results of monitoring of the program implementation process makes it possible to adjust them in due time.

Follow-up control provides feedback and an opportunity to assess the result of the financial support of programs, determine the ways and measures to improve the program budgeting system.

Data analysis is the main control method in all three cases. At the same time, in addition to the intermediate current control results and if obvious significant deviations are detected within the framework of follow-up control, inspections with a visit of the controlled objects can be carried out.

One of the strategic audit objectives is the assessment of risks of the achievement of strategic objectives stipulated by the programs as well as the objectives of the activities of audit objects. The introduction of a risk-oriented approach to the activities of public financial control authorities makes it possible to identify the presence and the degree of impact of internal and external conditions (factors) on the achievement of strategic goals and as a result focus audit activities on high-risk areas, which helps to reduce the level of risks related to

\footnotetext{
${ }^{6}$ See: The 2018-2024 Development Strategy of the Accounts Chamber of the Russian Federation // Official website of the Accounts Chamber of the Russian Federation: http://www.audit.gov.ru

${ }^{7}$ See: Federal Law No. 6-FZ of February 7, 2011 On the General Principles of the Organization and Activities of Control and Accounting Authorities of the Constituent Entities of the Russian Federation and Municipal Structures // Corpus of Legislative Acts of the Russian Federation No. 7 of February 14, 2011. Art. 903.
} 
the achievement of strategic goals. The need to manage systemic risks in addition to operational, organizational and other risks is noted in the Moscow Declaration signed following the $23^{\text {rd }}$ Congress of the International Organization of Supreme Audit Institutions (INTOSAI).

The use of strategic audit methods assumes the possibilities of processing and analyzing of large amounts of data obtained, inter alia, from monitoring, which requires a high level of the development of information technology, active use of the Big Data technology, cloud information storage. This, in its turn, requires significant financial costs for the up-to-date technical infrastructure of control processes, training and retraining of controllers.

It should be noted that there is practically no legal support of strategic audit at the level of the constituent entities of the Russian Federation, which makes it difficult to systematically and comprehensively control the efficiency of financing of sustainable development programs that are implemented throughout the country.

\section{References}

1. K. V. Agamirov, Forecasting as a Means of the Legal Policy in the Economic Sphere: The Domestic and Foreign Experience, State and Law, 10, 24-35 (2020)

2. S. A. Andreev, The International Experience of Exercising of Public Financial Control over the Implementation of Public-Private Partnership Projects, Financial Law, 6, 1619 (2021)

3. S. Barrett, S. Cobet, C. Larkin, Public Accountability and Parliamentary Scrutiny in Finance, European Journal of Risk Regulation, 11 (1), 94-108 (2020)

4. A. V. Bleschik, The Legal Expertise of Drafts of Legal Acts: A Communicative Approach, State and Law, 4, 162-167 (2020)

5. D. Chirwa, N. Amodu, Economic, Social and Cultural Rights, Sustainable Development Goals, and Duties of Corporations: Rejecting the False Dichotomies, Business and Human Right Journal, 6 (1), 21-41 (2021)

6. M. L. Galas, State and Political Measures of the Russian Federation to Achieve the Sustainable Development Goals in the Period of the Struggle against COVID-19 Taking into Account the Improvement of the Quality of Life of the Population, The Humanities. Bulletin of the Financial University, 11 (3), 82-88 (2021)

7. E. Galinovskaya, M. Ponomarev, Strategic Planning in the Natural Resource Sphere (a Legal Aspect), Pravo. Zhurnal Vysshey shkoly ekonomiki, 2, 65-86 (2021)

8. S. A. Gripich, Legal Aspects of the Introduction of Digital Technologies in Public Administration, Government and Local Self-Government, 2, 47-50 (2021)

9. K. Jacob, Regulatory Impact Assessment and Sustainable Development: Towards a Common Framework? European Journal of Risk Regulation, 1 (3), 276-280 (2010)

10. G. B. Kleyner, M. A. Rybachuk, The Experience of the Application of the Systemic Theory of State Influence in the Analysis of Economic Transformations: The Example of China and Russia, The Humanities. Bulletin of the Financial University, 9(2), 19-24 (2019)

11. E. Kudryashova, Financial Safety within Hierarchy of Strategic Planning Purposes in Russian Federation, Pravo. Zhurnal Vysshey shkoly ekonomiki, 2, 124-138 (2019)

12. I. B. Lagutin, Organizational and Legal Features of the Activities of Regional Control and Accounting Authorities of Russia Being Members of the European Organization of Regional Audit Institutions: on the Effectiveness of Membership in EURORAI, Financial Law, 1, 3-9 (2021) 
13. Measuring sustainable development. Report of the Joint UNECE/OECD/Eurostat Working Group on Statistics for Sustainable Development (2008). Access mode: https://www.oecd.org/greengrowth/41414440.pdf

14. M. M. Proshunin, State Digital Financial Control: The Legal Essence, Financial Law, 5, 3-7 (2021)

15. B. J. Richardson, Financing sustainability. The new Transnational Governance of Socially Responsible Investment, Yearbook of International Environmental Law, 17 (1), 73-110 (2006)

16. E. Ryabova, Public Financial Control: Identification of the Essence of the Phenomenon, Pravo. Zhurnal Vysshey shkoly ekonomiki, 2, 103-123 (2019)

17. M. A. Shichanin, On the Place of Digital Technologies in the Public Financial Control System, State and Law, 5, 154-158 (2021)

18. S. O. Shokhin, E. V. Kudryashova, Upravlenie finansovo-economicheskoy sferoy na osnove strategicheskogo planirovania [Management of the Financial and Economic Sphere Based on Strategic Planning: Legal Aspects]: monograph (2018)

19. S. O. Shokhin, E. V. Kudryashova, Performance information - the critical issue of public finance legal regulation, Law Enforcement Review, 4, 35-45 (2020)

20. S. O. Shokhin, Digitalization of State Financial Control, Financial Law, 6, 7-10 (2021)

21. Supreme Audit Institutions and Good Governance: Oversight, Insight and Foresight. OECD Public Governance Review (2016). Access mode: https://www.oecd.org/gov/ethics/supreme-audit-institutions-and-good-governance9789264263871-en.htm Accessed October, 25. 2021 